\title{
KETENTUAN HUKUM PERLINDUNGAN HAK ANAK JALANAN BIDANG PENDIDIKAN
}

\author{
Andi Muhammad Sofyan \\ Andi Tenripadang \\ Universitas Hasanuddin (UNHAS) Makassar \\ Sekolah Tinggi Agama Islam Negeri (STAIN) Parepare \\ Email: andimuhammadsofyan@unhas.ac.id \\ anditenripadang@stainparepare.ac.id
}

\begin{abstract}
National Education System, explains that education is a conscious and planned effort to create an atmosphere of learning and learning process so that learners actively develop their potential to have state power, self-control, personality of intelligence, noble character, as well as skills needed him, society, nation and country. Legal provisions for the protection of the rights of street children are legal provisions both at the level of laws, provincial and district / municipal regulations governing the protection, survival value, development, maintenance, welfare, education, physical health, moral social and mental spiritual. Legal provisions on the education of children should have a harmonious regulation both at the level of regulations issued by the government, provincial and municipal governments and districts that contain provisions both in terms of responsibility, to the involvement of the community in managing education based on the basic ideals of the Republic Indonesia
\end{abstract}

\begin{abstract}
Abstrak: Sistem Pendidikan Nasional, menjelaskan bahwa pendidikan adalah usaha sadar dan terencana untuk mewujudkan suasana belajar dan proses pembelajaran agar peserta didik secara aktif mengembangkan potensi dirinya untuk memiliki kekuatan negara, pengendalian diri, kepribadian kecerdasan, akhlak mulia, serta keterampilan yang diperlukan dirinya, masyarakat, bangsa dan Negara. Ketentuan hukum perlindungan hak anak jalanan adalah adanya ketentuan hukum baik ditingkat peraturan undang-undang, peraturan daerah tingkat provinsi, dan peraturan daerah tingkat kabupaten/kota yang mengatur adanya perlindungan, nilai kelangsungan hidup, perkembangan, pemeliharaan, kesehateraan, pendidikan, kesehatan fisik, moral sosial dan mental spiritual. Ketentuan hukum mengenai pendidikan anak harus memiliki keserasian regulasi baik ditingkat peraturan yang dikeluarkan oleh pemerintah, pemerintah provinsi, dan pemerintah kota dan kabupaten yang memuat adanya ketentuan baik dari segi tanggung jawab, hingga pada keterlibatan masyarakat dalam melakukan pengelolaan pendidikan yang berdasarkan pada cita dasar negara Republik Indonesia.
\end{abstract}

Kata Kunci: Hukum, Perlindungan, Anak Jalanan 


\section{PENDAHULUAN}

Pengertian pendidikan adalah sebagai usaha sadar dan terencana untuk mewujudkan suasana belajar dan proses pembelajaran untuk peserta didik secara aktif mengembangkan potensi dirinya untuk memiliki kekuatan spritual keagamaan, pengendalian diri, kepribadian, kecerdasan, akhlak mulia, serta keterampilan yang diperlukan dirinya dan masyarakat. Pendidikan dapat diartikan sebagai usaha sadar dan sistematis untuk mencapai taraf hidup atau untuk kemajuan lebih baik. Secara sederhana, pengertian pendidikan adalah proses pembelajaran bagi peserta didik untuk dapat mengerti, paham, dan membuat manusia lebih kritis berpikir.

Ketentuan Pendidikan sebagaimana Pasal 1 Undang-Undang Republik Indonesia Nomor 20 Tahun 2003 tentang Sisitem Pendidikan Nasional, menjelaskan bahwa pendidikan adalah usaha sadar dan terencana untuk mewujudkan suasana belajar dan proses pembelajaran agar peserta didik secara aktif mengembangkan potensi dirinya untuk memiliki kekuatan spritual keagamaan, pengendaalian diri, kepribadian kecerdasan, akhlak mulia, serta keterampilan yang diperlukan dirinya, masyarakat, bangsa dan negara.

Pendidikan adalah hal terpenting dalam kehidupan seseorang. Melalui pendidikan seseorang dapat dipandang terhormat, memiliki karir yang baik serta dapat bertingkah laku sesuai normanorma yang berlaku. Pendidikan adalah usaha sadar dan terencana secara etis, sistematis, intensional dan kreatif, dimana peserta didik mengembangkan potensi diri, kecerdasan, pengendalian diri dan ketrampilan untuk membuat dirinya berguna di masyarakat.

Pendidikan dapat diperoleh secara formal dan non formal. Pendidikan secara formal diperoleh dengan mengikuti program-program yang telah direncanakan, terstruktur oleh suatu institusi, departemen atau kementrian suatu negara. Sedangkan pendidikan non formal adalah pengetahuan yang diperoleh dari kehidupan sehari-hari dari berbagai pengalaman yang baik yang dialami atau dipelajari dari orang lain.

Tujuan pendidikan itu untuk menciptakan pribadi berkualitas dan memiliki karakter sehingga mempunyai visi yang luas ke depan untuk menggapai cita-cita yang diharapkan serta mampu beradaptasi secara efisien dalam berbagai lingkungan. Jadi salah satu konsep pendidkan itu sendiri adalah untuk sarana motivasi diri supaya menjadi lebih baik. Pendidikan bisa dimulai semenjak bayi masih berada dalam kandungan seperti yang banyak orang lakukan dengan memperdengarkan musik, membaca untuk sang bayi yang masih berada dalam kandungan atau mengajaknya bercakap-cakap. Hal ini dilakukan dengan harapan dapat memberi masukan ilmu kepada sang bayi sebelum proses kelahiran.

Tujuan Pendidikan Nasional adalah mencerdaskan kehidupan bangsa dan mengembangkan manusia Indonesia seutuhnya, yaitu manusia yang beriman dan bertaqwa kepada Tuhan Yang Maha Esa dan berbudi pekerti luhur, memiliki 
pengetahuan dan keterampilan, kesehatan jasmani dan rokhani, kepribadian yang mantap dan mandiri serta rasa tanggung jawab kemasyarakatan dan kebangsaan.

Tujuan pendidikan nasionalitas harus sesuai dengan TAP MPRS No XXVI/MPRS/1966 tentang Agama, Pendidikan dan Kebudayaan, sehingga dirumuskan bahwa tujuan dari pendidikan adalah membentuk manusia Pancasila sejati berdasarkan pembukaan Undang-undang Dasar 1945. Dalam Undang-undang Nomor 2 tahun 1989 juga ditegaskan bahwa tujuan pendidikan nasional adalah mencerdaskan kehidupan bangsa serta mengembangkan manusia Indonesia seutuhnya, dengan artian bahwa manusia yang beriman dan bertaqwa kepada Tuhan Yang Maha Esa, memiliki budi pekerti luhur, memiliki keterampilan dan pengetahuan, kesehatan jasmani dan rokhani, memiliki pribadi yang baik, mandiri dan memiliki rasa tanggung jawab kemasyarakatan, kebangsaan.

Sebagaimana Ketentuan Pasal 31 Ayat 3, bahwa:

"Pemerintah mengusahakan dan menyelenggarakan satu sistem pendidikan nasional, yang meningkatkan keimanan dan ketakwaan serta akhlah mulia dalam rangka mencerdaskan kehidupan bangsa, yang diatur dengan undangundang.

Sedangkan Ketentuan Pasal 31, Ayat 5 Bahwa:

"pemerintah memajukan ilmu pengetahuan dan teknologi dengan menjunjung tinggi nilai-nilai agama dan persatuan bangsa untuk kemajuan peradaban serta kesejahteraan umat manusia."

Penjabaran Undang-Undang Dasar NRI 1945 terkait pendidikan dituangkan dalam Undang-undang Nomor 20 Tahun 2003. Pasal 3 menyebutkan,

"Pendidikan nasional berfungsi mengembangkan kemampuan dan membentuk watak serta peradaban bangsa yang bermartabat dalam rangka mencerdaskan kehidupan, bertujuan untuk berkembangnya potensi peserta didik agar menjadi manusia yang beriman, bertakwa kepada Tuhan Yang Maha Esa, berakhlak mulia, sehat, berilmu, cakap, kreatif, mandiri dan menjadi warga negara yang demokratis serta bertanggung jawab.

Fungsi pendidikan bertujuan untuk menghilangkan segala sumber penderitaan rakyat yaitu kebodohan dan ketertinggalan. Menurut Undang-undang Sistem Pendidikan Naional No. 20 tahun 2003 menyatakan bahwa, "pendidikan nasional berfungsi mengembangkan kemampuan dan membentuk watak serta peradaban bangsa yang bermartabat dalam rangka mencerdaskan kehidupan bangsa".

\section{PEMBAHASAN}

\section{A. Pengertian Anak Jalanan}

Anak adalah amanah dan karunia Tuhan Yang Maha Esa, yang dalam dirinya melekat hakikat dan martabat sebagai manusia yang seutuhnya.

Pengertian anak terdapat dalam berbagai peraturan perundang-undangan yaitu Pasal 330 Ayat 1 Kitab Undangundang Hukum Perdata (KUHPerdata) 
bahwa belum dewasa adalah mereka yang belum mencapai umur genap dua puluh satu tahun dan tidak lebih dahulu telah menikah. Undang-undang Nomor 39 Tahun 1999 tentang Hak Asasi Manusia, (HAM) anak adalah setiap manusia yang berusia di bawah delapan belas tahun dan belum menikah termasuk anak yang berada dalam kandungan.

Kemudian, Konvensi Hak-hak Anak Tahun 1989, anak adalah setiap manusia yang berusia dibawah delapan belas tahun kecuali, berdasarkan undangundang yang berlaku untuk anak-anak, kedewasaan telah dicapai cepat, dan dalam UUPA memberikan defenisi pengertian anak adalah orang yang belum berusia delapan belas tahun termasuk anak yang masih dalam kandungan.

Anak yang dimaksud dalam hal ini adalah anak kandung, yaitu anak yang lahir dari perkawinan sah antara ayahnya dan ibunya adalah anak kandung yang sah. Ada kemungkinan dalam hidupnya ada seorang anak mengikuti ayahnya dan ibunya yang melahirkannya, ada kemungkinan hanya mengikuti ibu kandungnya tanpa ayah kandung, atau mungkin juga mengikuti ayah kandungnya tanpa ibu kandung. ${ }^{1}$

\section{B. Asas-asas Perlindungan Anak}

Upaya perlindungan hukum bagi anak dapat di artikan sebagai upaya perlindungan hukum terhadap berbagai kebebasan dan hak asasi anak (fundamental rights and freedoms of children) serta berbagai kepentingan yang berhubungan dengan kesejahteraan anak. Jadi Barda Nawawi Arief menyatakan masalah perlindungan hukum bagi anak mencakup ruang lingkup yang sangat luas. ${ }^{2}$

Pengentasan anak untuk mengembalikan dan menanamkan fungsi sosial anak. Fungsi ini mencakup ${ }^{3}$ suatu kombinasi dari berbagai keahlian teknik dan fasilitas-fasilitas khusus yang ditujukan guna tercapainya pemeliharaan fisik, penyesuaian sosial dan psikologis, penyuluhan dan bimbingan pribadi maupun kerja, latihan kerja serta penempatannya.

1. Asas Non Diskriminasi.

Asas non diskriminasi bahwa setiap orang berhak atas semua hak dan kebebasan yang dinyatakan didalamnya, tanpa perbedaan apa pun, seperti ras, warna kulit, jenis kelamin, bahasa, pandangan politik atau pendapat lain, asal kebangsaan dan sosial, harta kekayaan atau kedudukan lain.

2. Asas Kepentingan yang Terbaik Bagi Anak.

Yang dimaksud dengan asas kepentingan yang terbaik bagi anak adalah bahwa semua tindakan yang menyangkut anak yang dilakukan oleh pemerintah, masyarakat, badan legeslatif, dan badan yudikatif.

\section{Asas Hak Untuk Hidup, \\ Kelangsungan Hidup dan \\ Perkembangan.}

Yang dimaksud dengan hak asas hak untuk hidup, kelangsungan hidup dan perkembangan adalah hak asasi yang paling mendasar bagi anak yang 
dilindungi oleh negara, pemerintah, masyarakat, keluarga, dan orang tua.

\section{Asas Penghargaan Terhadap Pendapat Anak.}

Asas penghargaan terhadap pendapat anak adalah penghormatan atas hak-hak anak untuk untuk berpartisipasi dan menyatakan pendapatnya dalam pengambilan keputusan terutama jika menyangkut hal-hal yang mempengaruhi kehidupannya.

\section{Hak Dan Kewajiban Anak}

1. Hak Anak.

Mengenai tanggung jawab orang tua terhadap kesejahteraan anak meliputi kesehatan, pendidikan, pembinaan atau pembentukan kepribadian, hal ini lah yang merupakan timbulnya hak-hak anak. $^{4}$

Dasar hukum pengaturan hak-hak anak dapat dilihat dalam Pasal 4 sampai dengan Pasal 19 UUPA, dirumuskan hak-hak yaitu sebagai berikut:

a. Hak anak atas hidup, tumbuh kembang, perlindungan, dan partisipasi secara wajar.

b. Hak atas nama sebagai identitas diri dan status kewarganegaraan.

c. Hak untuk beribadah menurut agamanya, berpikir dan berekspresi.

d. Hak untuk mengetahui orang tuanya, dibesarkan dan diasuh orang tua.

e. Hak untuk diasuh atau diangkat oleh orang tua asuh atau orang tua angkat.

f. Hak memperoleh pelayanan kesehatan. g. Hak untu memperoleh jaminan sosial.

h. Hak untuk memperoleh pendidikan dan pengajaran.

i. Hak untu memperoleh pendidikan luar biasa bagi anak.

j. Hak memperoleh pendidikan khusus bagi anak yang memiliki keunggulan.

k. Hak untuk menyatakan dan didengar pendapatnya.

1. Hak menerima, mencari dan memberikan informasi.

m. Hak untuk beristirahat dan memanfaatkan waktu luang, bergaul dengan sebaya, bermain, berekreasi dan berkreasi.

n. Bagi anak yang menyandang cacat, berhak untuk:

1) Memperoleh rehabilitasi.

2) Bantuan sosial.

3) Pemeliharaan taraf kesejahteraan sosial.

o. Anak yang dalam status pengasuhan, berhak untuk dilindungi dari:

1) Diskriminasi.

2) Eksploitasi (ekomoni dan seksual).

3) Penelantaran.

4) Kekejaman, kekerasan, dan penganiayaan.

5) Ketidakadilan.

6) Perlakuan salah.

p. Hak untuk diasuh sendiri oleh orang tua sendiri.

q. Hak memperoleh perlindungan dari:

1) Penyalahgunaan dalam kegiatan politik. 
2) Pelibatan dalam sengketa bersenjata.

3) Pelibatan dalam kerusuhan sosial.

4) Pelibatan dalam peristiwa yang mengandung unsur kekerasan.

5) Pelibatan dalam peperangan.

r. Hak memperoleh perlindungan dari:

1) Penganiayaan.

2) Penyiksaan.

3) Penjatuhan hukuman yang tidak manusiawi.

s. Hak memperoleh kebebasan sesuai hukum.

t. Anak yang dirampas kemerdekaannya, berhak untuk:

1) Memperoleh perlakuan manusia.

2) Penempatan yang dipisah dari orang dewasa.

3) Memperoleh bantuan hukum.

4) Memperoleh bantuan lainnya.

5) Membela diri dan memperoleh keadilan di pengadilan yang objektif, tidak memihak, dan dalam sidang tertutup untuk umum.

u. Anak korban atau pelaku kekerasan seksual ataupun anak-anak yang berhadapan dengan hukum, berhak dirahasiakan identitasnya.

v. Hak memperoleh bantuan hukum, dan bantuan lainnya, baik korban atau pelaku tindak pidana.

Sedangkan dalam Pasal 1 huruf I Peraturan Daerah Kota Makassar No. 2 Tahun 2008 (Perda Kota Makassar N0. 2 Tahun 2008) tentang Pembinaan Anak Jalanan, Gelandangan, Pengemis, dan Pengamen di Kota Makassar. Bahwa hak anak adalah bagian dari hak asasi manusia yang wajib dijamin, dilindungi, dan dipenuhi oleh orang tua, keluarga, masyarakat, pemerintah dan negara.

Pada Pasal 44 Ayat 1 dan 2 bahwa Perda Kota Makassar No. 2 Tahun 2008 setiap anak, untuk dapat hidup, tumbuh, berkembang, dan berpartisipasi secara wajar dengan harkat dan martabat kemanusiaan serta mendapat perlindungan dari kekerasan diskriminasi. Setiap anak memperoleh pendidikan dan pengajaran dalam rangka pengembangan pribadi sesuai tingkat kecerdasan minat dan bakatnya.

2. Kewajiban Anak.

Di dalam UU No. 23 Tahun 2002, bukan hanya mengatur tentang perlindungan terhadap hak-hak anak tetapi juga mengatur mengenai kewajiban anak. Kewajiban anak tertuang dalam Pasal 19 UUPA yang meliputi:

a. Menghormati orang tua,

b. Mencintai keluarga, masyarakat dan menyayangi teman.

c. Mencintai tanah air, bangsa dan negara.

d. Menunaikan ibadah sesuai dengan ajaran agamanya.

e. Melaksanakan etika dan akhlak yang mulia.

Sedangkan, dalam Pasal 44 Ayat 3 Perda Kota Makassar No. 2 Tahun 2008 bahwa setiap anak berkewajiban untuk menghormati orang tua, wali, guru dan mencintai keluarga masyarakat, tanah air, bangsa dan negara, menyanyangi teman serta menunaikan ibadah sesuai denga ajaran agamanya sehingga dapat melaksanakan etika dan akhlak mulia. 


\section{Perlindungan Hukum}

Di dalam Kamus Besar Bahasa Indonesia, perlindungan berasal dari kata lindung yang memiliki arti mengayomi, mencegah, mempertahankan, dan membentengi.

Sedangkan perlindungan berarti konservasi, pemeliharaan, penjagaan, asilun, dan bunker. Beberapa unsur kata Perlindungan;

1. Melindungi: menutupi supaya tidak terlihat/ tampak, menjaga, memelihara, merawat, menyelamatkan.

2. Perlindungan; proses, cara, perbuatan tempat berlindung, hal (perbuatan) memperlindungi (menjadikan atau menyebabkan berlindung).

3. Pelindung: orang yang melindungi, alat untuk melindungi.

4. Terlindung: tertutup oleh sesuatu hingga tidak kelihatan.

5. Lindungan: yang dilindungi, cak tempat berlindung, cak perbuatan.

6. Memperlindungi: menjadikan atau menyebabkan berlindung.

7. Melindungkan: membuat diri terlindungi

Pengertian perlindungan dalam ilmu hukum adalah suatu bentuk pelayanan yang wajib dilaksanakan oleh aparat penegak hukum atau aparat keamanan untuk memberikan rasa aman, baik fisik maupun mental, kepada korban dan sanksi dari ancaman, gangguan, teror, dan kekerasan dari pihak manapun yang diberikan pada tahap penyelidikan, penyidikan, penuntutan, dan atas pemeriksaan di sidang pengadilan.

Di dalam ilmu hukum di kenal adanya subjek hukum, subjek hukum adalah pengemban hak dan kewajiban. Subjek hukum terdiri atas manusia dan badan hukum. Subjek hukum dapat melakukan tindakan-tindakan hukum sesuai kemampuan yang dimilikinya, dalam pergaulan di tengah masyarakat banyak terjadi hubungan hukum sebagai sebab akibat adanya tindakan-tindakan hukum dari subjek hukum tersebut, tindakan hukum ini merupakan awal lahirnya hubungan hukum yaitu interaksi antara subjek hukum yang memiliki relevansi hukum atau mempunyai akibat-akibat hukum.

Agar hubungan hukum antara subjek hukum itu berjalan harmonis, seimbang, adil, dalam arti setiap person hukum mendapat apa yang menjadi haknya dan menjalankan kewajiban yang dibebankan kepada hukum tampil sebagai aturan main dalam hubungan hukum tersebut.

Pelaksanaan hukum dapat berlangsung secara normal, damai, tapi dapat juga terjadi karena pelanggaran hukum, subjek hukum yang dilanggar haknya harus mendapatkan perlindungan hukum, seperti perlindungan hukum terhadap hak-hak anak jalanan.

Fungsi hukum sebagai instrumen pengatur dan instrumen perlindungan ini disamping fungsi lainnya yaitu diarahkan pada tujuan untuk menciptakan suasana hubungan hukum antara subjek hukum harmonis, seimbang dan adil. ${ }^{5}$ 
Untuk menjamin pelaksanaan hakhak anak berdasarkan Undang-undang Nomor 23 Tahun 2002 tentang Perlindungan Anak (UUPA) maka pemerintah wajib melakukan pengawasaan. Pengawasan yang dilakukan haruslah benar-benar bertujuan demi terlaksananya hak-hak anak, sehingga dibutuhkan suatu lembaga yang benar-benar diharapkan mampu untuk mewujudkan hak-hak anak sebagai mana yang diamanatkan oleh undang-undang. Untuk itu maka oleh negara dibentuklah suatu komisi yang khusus menangani seluruh aspek kehidupan anak, yaitu Komisi Perlindungan Anak Indonesia (KPAI) sesuai Pasal 74 UUPA.

Keanggotaan Komisi Perlindungan Anak Indonesia, terdiri dari unsur pemerintah, tokoh agama, tokoh masyarakat, organisasi sosial, organisasi kemasyarakatan, organisasi profesi, lembaga swadaya masyarakat, dunia usaha dan kelompok masyarakat yang peduli terhadap perlindungan anak.

Keanggotaan KPAI diangkat dan diberhentikan oleh presiden setelah mendapat pertimbangan Dewan Perwakilan Rakyat Republik Indonesia (DPR RI) untuk masa jabatan 3 (tiga) tahun dan dapat diangkat kembali untuk 1 (satu) kali masa jabatan.

Komisi Perlindungan Anak Indonesia bertugas melakukan sosialisasi seluruh ketentuan peraturan perundangundangan yang berkaitan dengan perlindungan anak, mengumpulkan data dan informasi, menerima pengaduan masyarakat, melakukan penelaahan, pemantauan evaluasi dan pengawasan terhadap penyelenggaraan perlindungan anak serta memberikan laporan, saran, masukan, dan pertimbangan kepada Presiden dalam rangka perlindungan anak.

Menurut Hadjon ${ }^{6}$, perlindungan hukum bagi rakyat meliputi 2 hal yakni:

1. Perlindungan Hukum Preventif, yakni bentuk perlindungan hukum dimana kepada rakyat diberi kesempatan untuk mengajukan keberatan atau pendapatnya sebelum suatu keputusan pemerintah mendapat bentuk yang definitif.

2. Perlindungan Hukum Represif, yakni bentuk perlindungan hukum dimana lebih ditujukan dalam penyelesaian sengketa.

1. Pengertian Perlindungan Hukum Ada beberapa pengertian tentang perlindungan hukum menurut para ahli yaitu:

a. Perlindungan hukum adalah memberikan pengayoman kepada hak asasi manusia yang dirugikan orang lain dan perlindungan tersebut diberikan kepada masyarakat agar mereka dapat menikmati semua hakhak yang diberikan oleh hukum.

b. Perlindungan hukum adalah perlindungan akan harkat dan martabat, serta pengakuan terhadap hak-hak asasi manusia yang dimiliki oleh subjek hukum berdasarkan ketentuan hukum dari kesewenangan.

c. Perlindungan hukum adalah berbagai upaya hukum yang harus diberikan oleh aparat penegak 
hukum untuk memberikan rasa aman, baik secara pikiran maupun fisik dari gangguan dan berbagai ancaman dari pihak manapun.

d. Perlindungan hukum adalah sebagai sekumpulan peraturan atau kaidah yang akan dapat melindungi suatu hal dari hal lainnya. Berkaitan dengan konsumen, berarti hukum memberikan perlindungan terhadap hak-hak pelanggan dari sesuatu yang mengakibatkan tidak terpenuhinya hak-hak tersebut.

e. Perlindungan hukum adalah penyempitan arti dari perlindungan, dalam hal ini hanya perlindungan oleh hukum saja. Perlindungan yang diberikan oleh hukum terkait pula dengan adanya hak dan kewajiban, dalam hal ini yang dimiliki oleh manusia sebagai subjek hukum dalam interaksinya dengan sesama manusia serta lingkungannya. Sebagai subjek hukum manusia memiliki hak dan kewajiban untuk melakukan suatu tindakan hukum.

Di dalam perlindungan hukum terdapat pula prinsip perlindungan hukum, prinsip perlindungan hukum terhadap tindakan pemerintah bertumpu dan bersumber pada konsep tentang pengakuan dan perlindungan terhadap hak-hak asasi manusia karena menurut sejaraah dari Barat, lahirnya konsepkonsep tentanag pengakuan dan perlindungan terhadaap hak-hak asasi manusia diarahkan kepada pembatasaanpembatasan dan peletakan kewajiban masyarakat dan pemerintah.

Aspek dominan dalam konsep Barat tentang hak asasi manusia menekankan eksistensi hak dan kebebasan yang melekat pada kodrat manusia dan statusnya sebagai individu, hak tersebut berada di atas negara dan di atas semua organisasi politik dan bersifat mutlak sehingga tidak dapat diganggu gugat. Karena konsep ini, maka seringkali dilontarkan kritik bahwa konsep Barat tentang hak-hak asasi manusia adalah konsep yang individualistik. Kemudian dengan masuknya hak-hak sosial dan hak-hak ekonomi serta hak kultural, terdapat kecenderungan mulai melunturnya sifat individualistik dari konsep Barat.

Dalam merumuskan prinsip-prinsip perlindungan hukum di Indonesia, landasannya adalah Pancasila sebagai ideologi dan falsafah negara. Konsepsi perlindungan hukum bagi rakyat di Barat bersumber pada konsep-konsep Rechtstaat dan "Rule of The law". Dengan menggunakan konsepsi Barat sebagai kerangka berpikir dengan landasan pada Pancasila, prinsip perlindungan hukum di Indonesia adalah prinsip pengakuan dan perlindungan terhadaap harkat dan martabat manusia yang bersumber pada Pancasila. Prinsip perlindungan hukum terhadap tindak pemerintah bertumpu dan bersumber darai konsep tentang pengakuan daan perlindungan terhadap hak-hak asasi manusia karena menurut sejarahnya di Barat, lahirnya konsep-konsep tentang pengakuan dan perlindungan terhadap hak-hak asasi manusia diarahkan kepada pembatasan-pembatasan dan peletakan kewajiban masyarakat dan pemerintah. 
Unsur lain yang dibutuhkan dalam pelaksanaan perlindungan hukum adalah sarana, dalam hal ini sarana perlindungan hukum.

Sarana perlindungan hukum ada 2 (dua) macam, yaitu:

a. Sarana perlindungan hukum preventif

Pada perlindungan hukum preventif ini, subjek hukum diberikan kesempatan untuk mengajukan keberatan atau pendapatnya sebelum suatu keputusan pemerintah mendapat bentuk yang defenitif. Tujuannya adalah mencegah terjadinya sengketa.

Perlindungan hukum preventif sangat besar artinya bagi tindak pemerintahan yang di dasarkan pada kebebasan bertindak karena dengan adanya perlindungan hukum yang preventif pemerintah terdorong untuk bersifat hati-hati dalam mengambil keputusan yang didasarkan pada diskresi. Di Indonesia belum ada pengaturan khusus mengenai perlindungan hukum secara preventif.

b. Sarana perlindungan hukum represif

Perlindungan hukum yang represif bertujuan untuk menyelesaikan sengketa. Penanganan perlindungan hukum oleh Pengadilan Umum dan Peradilan Administrasi di Indonesia termasuk kategori perlindungan hukum ini. Prinsip perlindungan hukum terhadap tindakan pemerintah bertumpu dan bersumber dari konsep tentang pengakuan dan perlindungan terhadap hak-hak asasi manusia karena menurut sejarah dari Barat, lahirnya konsep-konsep tentang pengakuan dan perlindungan hak-hak asasi manusia diarahkan kepada pembatasan-pembatasan dan peletakan kewajiban masyarakat dan pemerintah.

Prinsip kedua yang mendasari perlindungan hukum terhadap tindak pemerintahan adalah prinsip negara hukum. Dikaitkan dengan pengakuan dan perlindungan terhadap hak-hak asasi manusia, perlindungan tentanh hak-hak asasi manusia mendapat tempat utama dan dapat dikaitkan dengan tujuan dari negara hukum.

Dalam merumuskan prinsip perlindungan hukum bagi rakyat Indonesia, landasan berpijaknya adalah Pancasila sebagai dasar idiologi daan dasar falsafah negara. Pengakuan dan perlindungan terhadap harkat dan martabat manusia dikatakan bersumber pada Pancasila, karena pengakuan dan perlindungan terhadapnya secara instrisik melekat pada Pancasila. Selain bersumber pada Pancasila prinsip perlindungan hukum juga bersumber pada prinsip negara hukum.

2. Ketentuan Hukum Hak

Perlindungan Anak

a. Undang-undang Dasar/ Konstitusi

Majelis Umum Perserikatan BangsaBangsa (PBB) berdasarkan Resolusi No.44/23 tahun 1989 telah menetapkan hak-hak anak (Convention On The Right Of The Child/CRC) secara umum telah diterima atau diadopsi oleh 192 negara di seluruh dunia. CRC tersebut mencakup tiga nilai utama yaitu nilai perlindungan (protection), nilai kelangsungan hidup (survival) dan nilai perkembangan anak (development) anak. Pemerintah Indonesia merupakan salah 
satu dari bangsa bangsa dunia internasional yang telah meratifikasi $C R C$ tersebut dalam konteks nasional melalui Keputusan Presiden Republik Indonesia Nomor 36 Tahun 1990 (Kepres RI No. 36) tentang Pengesahan Convention On The Right Of The Child (Konvensi Tentang

Hak-Hak Anak).

Dasar nilai hubungannya dengan perlindungan terhadap anak, sebagaimana pembukaan Undangundang Dasar Negara Kesatuan Republik Indonesia (UUD NKRI) 1945 bahwa:

Kemudian dari pada itu untuk membentuk suatu pemerintah negara Indonesia yang melindungi segenap bangsa Indonesia dan seluruh tumpah darah Indonesia dan untuk memajukan kesejahteraan umum, mencerdaskan kehidupan bangsa, dan ikut melaksanakan ketertiban dunia yang berdasarkan kemerdekaan, perdamaian abadi dan keadilan sosial, maka disusunlah kemerdekaan kebangsaan Indonesia itu dalam suatu undangundang dasar negara Indonesia, yang terbentuk dalam suatu susunan negara Republik Indonesia yang berkedaulatan rakyat dengan berdasarkan kepada Ketuhanan Yang Maha Esa, Kemanusiaan Yang Adil dan Beradab, Persatuan Indonesia dan Kerakyatan yang dipimpin oleh hikmat kebijaksanaan dalam Permusyawaratan/Perwakilan, serta dengan mewujudkan suatu Keadilan Sosial bagi seluruh rakyat Indonesia.

Sekaitan dengan pembukaan tersebut di atas, sebagai turunan sebagaimana Pasal 28B Ayat 2 UUD NKRI 1945 bahwa setiap anak berhak atas kelangsungan hidup, tumbuh dan berkembang serta berhak atas perlindungan dari kekerasan dan diskriminasi, kemudian Pasal 33 Ayat 3 UUD 1945 bahwa:

Bumi dan air dan kekayaan alam yang terkandung di dalamnya dikuasai oleh negara dan dipergunakan untuk sebesar-besarnya kemakmuran rakyat.

Sedangkan ketentuan Pasal 34 Ayat 1 UUD NKRI 1945 bahwa fakir miskin dan anak terlantar dipelihara oleh negara.

Pada dasarnya ketentuan adanya perlindungan anak pada konstitusi negara Republik Indonesia telah mengatur adanya perlindungan baik dari segi kecerdasan (pendidikan) perlindungan dari kehidupan (hidup yang layak), maka dengan demikian diperlukan adanya instrumen di dalam melaksankaan cita dasar konstitusi. Instrumen di dalam melaksanakan cita dasar konstitusi adalah pertama adanya instrumen hukum dan intrsumen pemerintahan yang di berikan kewenangan didalam melakukan perlindungan terhadap anak.

Instrumen hukum di maksudkan sebagai ketersediaan peraturan perundang-undangan yang memadai di dalam memberikan perlindungan terhadap hak hak anak. Hal tersebut dimaksudkan karena negara Indonesia sebagai negara hukum, maka tentunya segala sesuatu terkait dengan 
penyelenggaraan pemerintahan adalah harus berdasarkan hukum yang berlaku.

Instrumen pemerintah dimaksudkan adalah adalah pendelegasian kewenangan kepada pemerintah baik di tingkat pusat provinsi hingga pada daerah kabupaten/kota di dalam melaksanakan perlindungan terhadap anak.

Kedua indikator pada instrumen tersebut merupakan dasar di dalam melakukan perlindungan terhadap anak di dalam mewujudkan masyarakat adil dan makmur sebab bagaimanapun anak merupakan pelanjut generasi bangsa yang tentunya dibutuhkan akan potensi cukup yang diharapkan mampu mempertahankan keutuhan negara Republik Indonesia.

Instrumen di dalam melakukan perlindungan terhadap anak, sebagaimana di uraikan dalam berbagai ketentuan ketentuan hukum yang dijelaskan pada pejelasan di bawah ini.

b. Analisis Undang-undang Tentang Anak

1) Analisis Undang Undang

Perlindungan Anak

Undang-Undang Dasar Negara Republik Indonesia Pasal 28B Ayat (2) mengatur secara tegas mengenai hak setiap anak atas kelangsungan hidup, tumbuh dan berkembangnya serta berhak atas perlindungan dari kekerasan dan diskriminasi. Ketentuan tersebut ditindak lanjuti dalam Undang-undang Nomor 23 Tahun 2002 tentang Perlindungan Anak Pasal 23 ayat (1) yang berisi :

Negara dan pemerintah menjamin perlindungan, pemeliharaan, dan kesejahteraan anak dengan memperhatikan hak dan kewajiban orang tua, wali, atau orang lain yang secara hukum bertanggung jawab terhadap anak.

Berdasarkan Konvensi Hak Anak Perserikatan Bangsa-Bangsa tahun 1989 juga telah diuraikan secara jelas mengenai hak anak yaitu: hak untuk bermain, hak untuk mendapatkan perlindungan, hak untuk mendapatkan nama (identitas), hak untuk mendapatkan status kebangsaan, hak untuk mendapatkan makanan, hak untuk mendapatkan akses kesehatan, hak untuk mendapatkan rekreasi, hak untuk mendapatkan kesamaan, dan hak untuk memiliki peran dalam pembangunan.

Undang-undang Nomor 23 Tahun 2002 tentang Perlindungan Anak Pasal 1 Ayat (15) juga menyebutkan bahwa anak diberikan perlindungan khusus . Adapun yang dimaksudkan dalam Pasal 1 Ayat (15) Undang-undang Nomor 23 Tahun 2002 tentang Perlindungan Anak yaitu:

Perlindungan khusus adalah perlindungan yang diberikan kepada anak dalam situasi darurat, anak yang berhadapan dengan hukum, anak dari kelompok minoritas dan terisolasi, anak yang dieksploitasi secara ekonomi dan/seksual, anak yang diperdagangkan, anak yang menjadi korban penyalahgunaan narkotika, alkohol, psikotropika, dan zat adiktif lainnya (napza), anak korban penculikan, penjualan, perdagangan, anak korban kekerasan baik fisik dan/mental, anak yang menyandang cacat, dan anak korban perlakuan salah dan penelantaran."

Ketentuan perlindungan pada anak 
sebagaimana dimaksudkan dalam peraturan di atas adalah guna terpenuhinya hak-hak terhadap anak untuk dapat berkembang dan bertahan hidup, serta juga dapat berpatisipasi dalam masyarakat, dengan terhindar dari eksploitasi khususnya secara ekonomi.

Terhadap eksploitasi sebagaimana kriteria UNICEFyaitu bila menyangkut:

a) Kerja penuh waktu (full time) pada umur yang terlalu dini;

b) Terlalu banyak waktu digunakan untuk bekerja;

c) Pekerjaan menimbulkan tekanan fisik, sosial, dan psikologis yang tidak patut terjadi;

d) Upah yang tidak mencukupi;

e) Tanggung jawab yang terlalu banyak;

f) Pekerjaan yang menghambat akses pendidikan;

g) Pekerjaan yang mengurangi martabat dan harga diri anak, seperti : perbudakan atau pekerjaan kontrak paksa dan eksploitasi seksual;

h) Pekerjaan yang merusak perkembangan sosial serta psikologis yang penuh. 7

c. Analisis Undang-undang Peradilan Anak

Undang-undang Sistem Peradilan Pidana Anak pengganti dari Undangundang Nomor 3 Tahun 1997 tentang Pengadilan Anak ("UU Pengadilan Anak") adalah bertujuan untuk terwujud peradilan yang benar-benar menjamin perlindungan kepentingan terbaik terhadap anak yang berhadapan dengan hukum. Perubahan Undang-undang Pengadilan Anak pada dasarnya sudah tidak sesuai kebutuhan hukum masyarakat, dalam hal ini adalah secara komprehensif belum memberikan perlindungan khusus kepada anak yang berhadapan dengan hukum.

Pada dasarnya bahwa substansi pengaturan mengenai Undang-undang Peradilan Anak adalah dengan mengedepankan adanya keadilan restoratif dan diversi, yaitu sebagai upaya di dalam menghindarkan dan atau menjauhkan anak dari proses peradilan. Dengan demikian maka tidak melahirkan stigmatisasi terhadap anak, sehingga anak tersebut dapat kembali ke dalam lingkungan masyarakat.

Pemahaman keadilan restoratif terhadap anak adalah sebagai upaya di dalam melibatkan semua kalangan baik dari korban, pemerintah masyarakat dalam rangka mencari solusi atas permasalahan yang timbul pada anak untuk memperbaiki, rekonsiliasi dan menenteramkan hati korban (anak) pada intinya bawa keadilan restoratif bukan pada pembalasan melalui hukuman.

Sedangkan diversi dimaksudkan sebagai pengalihan penyelesaian perkara anak di pegadilan untuk keluar pengadilan.

Sebagaimana pandangan Muliyawa ${ }^{8}$ bahwa seorang anak (pelaku) yang diusianya yang masih sangat muda tetapi sudah berani melakukan perbuatan yang melanggar hukum (melakukan tindak pidana), pada dasarnya anak tersebut bukanlah seorang anak yang "jahat" sehingga kita tidak boleh terlalu cepat memberikan label kepada anak tersebut sebagai seorang "penjahat" atau label 
apa saja yang bisa membuat anak tersebut tidak nyaman dalam berinteraksi sosial, karena pada dasarnya anak tersebut adalah korban dari sebuah sistem sosial yang diakibatkan oleh beberapa faktor seperti faktor lingkungan dan sosial yang tidak sehat, terpengaruh dengan budaya konsumerisme, serta tidak adanya panutan yang positif dalam keluarganya (broken home) yang bisa dijadikan panutan si anak dalam menjalani kehidupannya. Dan faktor-faktor tersebutlah membuat si anak yang merasa mulai terkucilkan dan diasingkan oleh lingkungan sosialnya mengambil jalan pintas untuk eksis dengan melakukan berbagai macam tindak pidana, seperti bergabung dengan temantemannya (yang merasa senasib) membuat suatu komunitas misalnya membentuk "komunitas geng motor".

Jauh sebelumnya hal tersebut sudah pernah dikemukukan oleh salah seorang maha guru hukum pidana yang bernama Separovic yang menyatakan, bahwa: "Ada dua faktor yang menyebabkan terjadinya kejahatan yaitu (1) faktor personal, termasuk di dalamnya faktor biologis (umur, jenis kelamin, keadaan mental dan lain-lain) dan psikologis (agresivitas, kecerobohan, dan keterasingan), dan (2) faktor situasional, seperti situasi konflik, faktor tempat dan waktu".

Dengan demikian berdasarkan uraian di atas pada dasarnya pengaturan pada perlindungan anak terhadap undang-undang pengadilan anak adalah menekankan pada tindakan solutif yang dilakukan terhadap korban dengan melibatkan kalangan yang berkepentingan baik pemerintah, masyarakat, dengan menyelesaikannya di luar pengadilan.

Secara analisis eksistensi anak terhadap peraturan peradilan anak bahwasanya; keberadaan anak adalah tidak lepas dari pada pada lingkungan masyarakat yang setiap harinya bermain dan bersama dengan masyarakat disekitarnya, baik buruknya anak-anak juga sangat ditentukan oleh lingkungan masyarakat itu sendiri. Demikian juga pada tataran pemerintahan bahwasanya anak akan tumbuh besar dan berkembang tentunya sebagai harapan bangsa untuk menjadi generasi penerus.

Olehnya itu sebuah kesadaran bahwasanya bangsa memiliki ketergantungan besar tehadap anak sebagai generasi pelanjut. Di lain sisi, proses peradilan merupakan proses hukum yang bukan hanya berpengaruh pada hak anak untuk menikmati masa kecil untuk bernmain akan tetapi juga akan berpengaruh secara psikologi yang tentunya akan terbawa hingga mereka besar nanti.

Olenya itu, peradilan anak sangatlah penting di dalam meberikan perlindungan kepada anak atas segala tindakannya, tentunya dengan memberikan perlindungan bukan berarti membebaskan dari hukuman atas perbuatannya. Namun demikian memberikam hukuman yang tentunya tidak sama dan serupa dengan orang dewasa didalam menjalankan hukuman. 
Hal tersebut di sebabkan, anak memiliki tingkat emosiaonal yang masih sangat rendah, daya ingat yang sangat tinggi dan prikologi yang bisa terbawa hingga kelak ia telah beranjak dewasa.

Sebagaimana dalam kaedah peraturan tentang peradilan anak bahwa anak yang dikenakan sanksi tindakan ${ }^{9}$ dapat saja berupa:

- pegembalian kepada orang tua wali;

- penyerahan kepada seseorang;

- perawatan rumah sakit jiwa;

- perawatan di LPKS;

- kewajiban mengikuti pendidikan formal dan atau pelatihan yang dilakukan oleh pemerintah atau badan swasta;

- pencabutan surat ijin mengemudi; dan atau

- perbaikan akibat tidak pidana.

Sedangkan kaedah sanksi pidana terhadap anak terdiri atas pidana pokok dan pidana tambahan yakni:

Pertama, pidana pokok yaitu:

- pidana peringatan;

- pidana dengan syarat, terdiri atas; pembinaan di luar lembaga, pelayanan masyarakat, atau pengawasan;

- pelatihan kerja;

- pembinaan dalam lembaga;

- penjara.

Kedua, pidana tambahan yakni:

- perampasan keuntungan yang diperoleh dari tindak pidana;

- pemenuhan kewajiban adat.

2) Analisis Undang-undang Hak Asasi Manusia Terhadap Anak
Anak merupakan karunia Allah Subhanah Wataalah yang melekat pada anak. Sebagaimana anak, anak merupakan tunas, potensi, dan generasi muda penerus cita-cita perjuangan bangsa, pada dasarnya anak memiliki peran penting sebagai pelanjut dalam mengisi peran pemerintahan dan masyarakat demikian pada sektor swasta. Olenya itu masyarakat dan pemerintah harus bertanggungjawab di dalam menjaga kelangsungan hidup anak.

Pada Ketentuan Pasal 28B ayat (2) Undang-undang Dasar Negara Republik Indonesia menyebutkan bahwa:

"setiap anak berhak atas kelangsungan hidup, tumbuh dan berkembang serta berhak atas perlindungan dari kekerasan dan diskriminasi."

Sedangkan di dalam Pasal 52 ayat (2) Bab III Undang-undang Nomor 39 Tahun 1999 tentang Hak Asasi Manusia bahwa:

"hak anak adalah hak asasi manusia dan untuk kepentingannya hak anak itu diakui dan dilindungi oleh hukum bahkan sejak dalam kandungan."

Sedangkan terkait dengan pembatasan terhadap anak sebagaimana diatur dalam ketentuan Pasal 1 angka 5 Undang-undang tentang Hak Asasi Manusia yaitu:

"Setiap manusia yang berusia di bawah 18 (delapan belas) tahun dan belum menikah, termasuk anak yang masih dalam kandungan apabila hal tersebut adalah demi kepentingannya"

Sedangkan pembatasan anak sebagaimana dalam Pasal 1 angka 1 
Undang-undang Nomor 23 Tahun 2002 tentang Perlindungan Anak yang menyebutkan bahwa anak adalah seseorang yang belum berusia 18 (delapan belas) tahun, termasuk anak yang masih dalam kandungan.

Perlindungan anak merupakan salah satu bagian dari hak asasi manusia sebagaimana negara Indonesai memberikan jaminan terhadap kesejateraan disetiap warganegara. Sebagai upaya didalam melakukan perlindungan terhadap anak adalah melalui pemerintah dengan adanya usaha yang tujuannya adalah menjamin adanya perlindungan dan kesejahteraan. Jaminan perlindungan terhadap anak adalah dengan adanya peran pemerintah sebagai regulator dengan membentuk Undangundang Nomor 23 Tahun 2002 tentang Perlindungan Anak.

Sekaitan dengan perlindungan anak sebagaimana dalam ketentuan Pasal 1 angka 2 Undang-undang Nomor 23 Tahun 2002 tentang Perlindungan Anak merupakan suatu kegiatan untuk:

pertama, menjamin dan melindungi anak dan hak-haknya agar dapat hidup, tumbuh, berkembang, dan berpartisipasi secara optimal sesuai dengan harkat dan martabat kemanusiaan, serta mendapat perlindungan dari kekerasan dan diskriminasi.

Kedua, sedangkan Pasal 3 Undangundang tentang Perlindungan Anak menyebutkan bahwa Perlindungan anak bertujuan untuk menjamin terpenuhinya hak-hak anak agar dapat hidup, tumbuh, berkembang dan berpartisipasi secara optimal sesuai dengan harkat dan martabat kemanusiaan, serta mendapat perlindungan dari kekerasan dan diskriminasi demi terwujudnya anak Indonesia yang berkualitas, berakhlak mulia dan sejahtera.

Berkaitan dengan hak anak dalam Undang-undang tentang Hak Asasi Manusia diatur dalam ketentuan Pasal 52 sampai dengan Pasal 66 yang antara lain meliputi hak adalah adanya perlindungan oleh orang tua, keluarga, masyarakat, dan negara. Secara kodrati bahwa hak anak bahwasanya sejak anak dalam kandungan anak memerlukan perlindungan untuk hidup, selanjuntya saat ia lahir maka ia akan mepertahankan hidupnya, dan bukan hanya mempertahankan akan tetapi juga menginkan adanya peningkatan taraf hidup.

Lebih lanjut, bahwa anak membutuhan adanya pengakuan oleh negara sebagai warga negara yang tentunya memiliki hak dan kewajiban sama dengan anak- anak lainnya dan atau warga negara lainnya. Bentuk perlindungan lainnya dimana menjadi urusan negara adalah terkait dengan anak yang cacat fisik dan/atau mental dalam hal ini adalah pemerintah menyediakan fasilitas untuk memperoleh perawatan, demikian pada pendidikan, pelatihan untuk disediakan oleh negara.

Terhadap anak dalam rangka mendapatkan perlindungan hukum dari segala bentuk kekerasan fisik atau mental, penelantaran, perlakuan buruk, dan pelecehan seksual selama dalam pengasuhan orang tua atau walinya, atau 
pihak lain manapun yang bertanggung jawab atas pengasuhan anak tersebut.

Sedangkan perlindungan dari kegiatan eksploitasi ekonomi dan setiap pekerjaan yang membahayakan dirinya sehingga dapat mengganggu pendidikan, kesehatan fisik, moral, kehidupan sosial dan mental spiritualnya.

Sebagai bentuk tanggungjawa bahwasanya negara Republik Indonesia bertanggung jawab dalam rangka menghormati dan menjamin hak asasi setiap anak tanpa membedakan suku, agama, ras, golongan, jenis kelamin, etnik, budaya dan bahasa, status hukum anak, urutan kelahiran anak, dan kondisi fisik dan/atau mental.

Sebagaimana dalam ketentuan Pasal 21 dan Pasal 22 Undang-undang tentang Perlindungan Anak, negara dan pemerintah juga berkewajiban serta bertanggung jawab untuk memberikan dukungan sarana dan prasarana dalam penyelenggaraan perlindungan anak. Pengaturan mengenai kewajiban dan tanggung jawab negara dan pemerintah.

Terhadap ketentuan undang-undang hak asasi manusia pada dasarnya memberikan ruang kepada anak untuk diberikan perlindungan baik dalam pendidikan, fasilitas dan lainnya.

Olehnya itu sebagai upaya di dalam melaksanakan peraturan perundangundangan ini maka diperlukan adanya instrumen hukum yang memadai sebagai pedoman di dalam memberikan perlindungan hukum terhadap anak. Hal ini dimaksudkan karena anak merupakan harapan masa depan bangsa, negara, masyarakat, dan agama. d. Peraturan Tingkat Daerah

Instrumen dalam rangka memberikan perlindungan hukum terhadap anak dengan adanya peraturan perundang-undangan lebih mulai dari Undang-undang Dasar Negara Republik Indonesia 1945, Undang-undang tentang Perlindungan Anak hingga pada Undang-undang Hak Asasi Manusia. Secara hierarki ketentuan telah memadai untuk dijadikan sebagai dasar dimana pemerintah daerah mengikuti peraturan tersebut yang selanjutnya menciptakan regulasi sekaitan dengan perlindungan anak. Regulasi yang dimaksudkan adalah dengan adanya ketersediaan Peraturan Daerah (Perda) yang berkesesuaian antara ketentuan hukum dan kondisi masayarakat.

Bahwasanya ketentuan peraturan daerah diperlukan oleh karena instrumen pelaksanaan peraturan perundangundangan tidak mengatur secara spesifik berdasarkan kondisi daerah maka dengan demikian dengan adaya Perda, maka daerah mampu mengatur daerah berdasarkan kepentingan dan kebutuhan daerah masing-masing dengan tetap berlandaskan pada ketentuan hukum yang lebih tinggi, seperti undang-undang dasar dan undang-undang atau peraturan perundang-undangan diatas Peraturan Daerah.

\section{PENUTUP}

Ketentuan hukum perlindungan hak anak jalanan adalah adanya ketentuan hukum baik ditingkat peraturan undang-undang, peraturan daerah tingkat provinsi, dan peraturan 
daerah tingkat kabupaten/kota yang mengatur adanya perlindungan (protection), nilai kelangsungan hidup (survival), perkembangan (development), pemeliharaan, kesejahteraan, pendidikan, kesehatan fisik, moral sosial dan mental spiritual. Maka Harusnya ketentuan hukum megenai pendidikan anak adalah memiiliki keserasian regulasi baik ditingkat praturan yang dikeluarkan oleh pemerintah, pemerintah provonsi, dan pemerintah kota dan kabupaten yang memuat adanya ketentuan baik dari segi tanggung jawab, hingga pada keterlibatan masyarakat di dalam melakukan pengelolaan pendidikan yang berdasarkan pada cita dasar negara Republik Indonesia.

\section{Catatan Akhir:}

${ }^{1}$ Chandra Halim. Perlindungan Hukum Terhadap Anak di Bidang Kesejahteraan. Universitas Atma Jaya. Yogyakarta. Hal : 266.

${ }^{1}$ Barda Nawawi Arief. 1998. Beberapa Aspek Kebijakan Penegakan dan Pengembangan Hukum Pidana. Citra Aditya Bakti. Bandung. Hal. 15

${ }^{1}$ Shanty Dellyana, 1998. Wanita dan Anak di Mata Hukum, Liberty. Yogyakarta. Hal. 15

${ }^{1}$ Arief Gosita. 1991. Masalah Perlindungan Anak. Liberty. Yogyakarta. Hal. : 21

${ }^{1}$ Sudikno Mertokusumo. Mengenal Hukum Suatu Pengantar, Liberty. Yogyakarta. 1996. Hal. 140

${ }^{1}$ Philipus M. Hadjon., 1987, Perlindungan Hukum bagi Rakyat Indonesia.Surabaya : Bina Ilmu. Hal. 117

${ }^{1}$ Aris Ananta. Pekerja Anak di Indonesia. Gramedia Widiasarana Indonesia. Jakarta,. Hal. 174

${ }^{1}$ Mulyawan Opini "Anak adalah amanah dan karunia Tuhan YME, yang dalam dirinya melekat harkat dan martabat sebagai manusia seutuhnya dan anak bukanlah miniatur orang dewasa" Dimuat di surat kabar harian Palopo Pos pada Kamis, 22 Januari 2015

${ }^{1}$ Pasal 82 UU SPPA

\section{DAFTAR PUSTAKA}

Chandra Halim. Perlindungan Hukum Terhadap Anak di Bidang Kesejahteraan. Universitas Atma Jaya. Yogyakarta.

Barda Nawawi Arief. 1998. Beberapa Aspek Kebijakan Penegakan dan Pengembangan Hukum Pidana. Citra Aditya Bakti. Bandung.

Shanty Dellyana, 1998. Wanita dan Anak di Mata Hukum, Liberty. Yogyakarta.

Arief Gosita. 1991. Masalah Perlindungan Anak. Liberty. Yogyakarta.

Sudikno Mertokusumo. Mengenal Hukum Suatu Pengantar, Liberty. Yogyakarta. 1996.

Philipus M. Hadjon., 1987, Perlindungan Hukum bagi Rakyat Indonesia.Surabaya : Bina Ilmu.

Aris Ananta. Pekerja Anak di Indonesia. Gramedia Widiasarana Indonesia. Jakarta, .

Mulyawan Opini “Anak adalah amanah dan karunia Tuhan YME, yang dalam dirinya melekat harkat dan martabat sebagai manusia seutuhnya dan anak bukanlah miniatur orang dewasa" Dimuat di surat kabar harian Palopo Pos pada Kamis, 22 Januari 2015 